\title{
Effect of Plant Density on Marketable Yield, Tuber Number, and Mean Weight of Three Tanier Cultivars ${ }^{1}$
}

\author{
Héber Irizarry and Angel Acosta Matienzo²
}

\section{INTRODUCTION}

The edible starchy tubers of several species of Xanthosoma, commonly known as tanier, have been an important part of the diet of the inhabitants of Tropical America since remote pre-Colombian times. Tanier at present is the second most important root-crop grown in Puerto Rico where the tubers are consumed in many and varied ways. The produce generally is marketed fresh, although recently it also is being marketed as canned puree and in frozen-ground form. Food processing research is being conducted to determine the feasibility of marketing it also in frozen-peeled and frozenflour forms. It is to be expected that these new developments in food technology will increase consumption of taniers in Puerto Rico.

The very fact that tanier is a healthy crop, with relatively few agronomic problems, these factors have resulted in the retarding of research and in the updating of agricultural practices in use by farmers for many years. Improvement in local practices of cultivation is thus hampered by the limited information available pertaining to varietal response in relation to plant density.

Generally, taniers are planted 3 feet between rows and 2 feet within the row. Barrett (3) in 1905 suggested that a planting distance of 3 by $11 / 2$ feet, respectively, appeared suitable for local conditions. Abrufa-Rodríguez et al. (1), using different planting distances, did not detect any effect from spacing on the yield of the Morada variety under favorable weather conditions at Adjuntas, but reported a significant yield increase with an increase in plant population under reduced rainfall at Orocovis. However, Enyi (4) in Nigeria obtained highest yields with the wider spacing of 5 by 5 feet.

This study was conducted for the purpose of evaluating the effect of plant spacing and plant density on yields of the three commercially grown tanier cultivars Blanca del País, Kelly, and Morada. All three are of exceptionally good quality.

1 Manuscript submitted to Editorial Board March 29, 1973.

- Associate Plant Breeder and Associate Agronomist, respectively, Agricultural Experiment Station, Mayagüez Campus, University of Puerto Rico, Río Piedras, P.R. 


\section{MATERIALS AND METHODS}

An experimental planting was made on August 9, 1971 at the Gurabo Substation in a Toa clay loam soil ${ }^{8}$ with a $\mathrm{pH}$ of 5.5. Four plant spacings with their corresponding plant densities and the three tanier cultivars were arranged in a factorial design.

The planting treatments and plant densities per acre were: 3 by 2 feet, 7,260 plants; 3 by 11/2 feet, 9,680 plants; 2 by 2 feet, 10,890 plants; 2 by $11 / 2$ feet, 14,520 plants, respectively.

The cultivar Blanca del Pais has white-flesh and produces large, uniform, bottle-shaped tubers with long thin necks. The skin is rough, free of protruding eyes, and gray in color; the apical bud is creamy-white.

Kelly is an early maturing, yellow-fleshed cultivar characterized by uniform shortnecked stout tubers with smooth hazel color skin. The apical bud is creamy-yellow.

Morada produces large, uniform, bottle-shaped tubers with fairly long, rather stout necks. The outer skin is smooth, purple-gray in color and the apical bud is purple-red. The flesh is light purple.

The experimental plots were 12 feet long and either 9 or 10 feet wide depending upon the plant spacing. Each plot contained 18 to 40 plants surrounded by border rows.

Planting was by hand in plowed unfurrowed soil. The seed material consisted of pieces of rhizomes having at least two germinal buds and weighing about 3 ounces each. The seed was dipped for 5 minutes prior to planting in a fungicide solution containing $5 \mathrm{~g}$ each of Dexon and Benlate per gallon of water.

To control weeds, a pre-emergence application of 4 pounds of Ametryne per acre in $\mathbf{5 0}$ gallons of water was applied immediately after planting. Subsequently, the experimental field was hand-weeded twice.

Two months after planting a fertilizer mixture containing 100 pounds of $\mathrm{N}, 92$ pounds of $\mathrm{P}_{5} \mathrm{O}_{5}$ and 120 pounds of $\mathrm{K}_{2} \mathrm{O}$ per ton was applied at the rate of 2 ounces per plant.

Weekly rainfall was recorded (fig. 1) throughout the growing period of the experiment. Supplementary overhead irrigation was applied as needed to compensate for insufficient rainfall.

The experiment was harvested June 7, 1972, 10 months from planting date. At harvest, the tubers were classified either marketable or non-marketable. Data as to marketable yield and number of marketable tubers were recorded, and the tuber mean weight determined.

- Toa clay loam is a soil found in river flood plains, formed from material washed from the interior hills, which is carried and distributed by silt-laden overflowing streams. The plains are nearly level, have good drainage, are friable and deep, thus being almost ideal for maximum agricultural utilization. They contain considerable organic matter, sand and soil nutrients, and are slightly acid (5). 


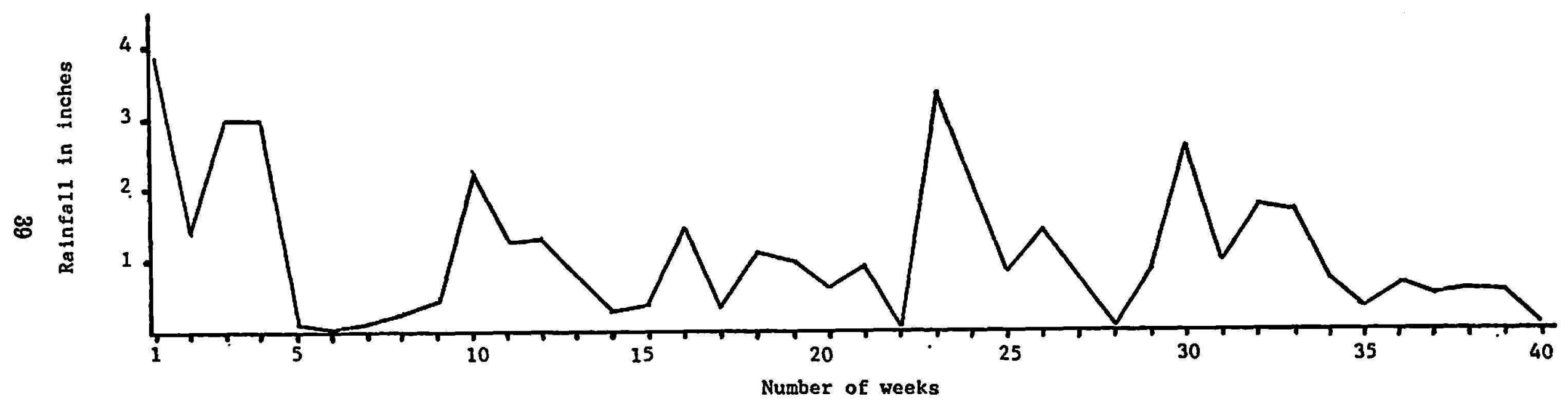

FiG. 1.-Weekly rainfall distribution from August 9, 1971 to May 14, 1972 at the Gurabo Substation. 


\section{RESULTS AND DISCUSSION}

The statistical analysis of the data showed no significant effect of plant spacing $X$ cultivar interaction for the plant attributes under investigation, i.e. marketable yield, number of marketable tubers, and mean tuber weight. This indicates these cultivars responded similarly to planting treatments.

The combined plant spacing of 2 by $11 / 2$ feet with a density of 14,520 plants per acre significantly outyielded the other planting treatments (table 1). It outyielded the combined planting of 3 by 2 feet with a density of 7,260 plants per acre at the 1-percent level of probability, and the combined plantings of 2 by 2 and 3 by 11/2 feet with densities of 10,890 and 9,680 plants per acre, respectively, at the 5-percent level of probability. Yield differences between the 2 by $11 / 2$ feet and 3 by 2 feet spacings were 26.8 hundredweights per acre. These results are somewhat similar to those obtained by Abruna-Rodriguez et al. (1), who detected a significant yield

TABLE 1.-Estimated yield and number of marketable tanier tubers as affected by plant spacing and density

\begin{tabular}{cccc}
\hline Plant spacing & Plant density per acre & Yield estimate per acre & Tubers per plot \\
\hline Peet & Number & Eundredreights & Number \\
$2 \times 11 / 2$ & 14,520 & $80.6 \mathrm{al}^{\mathrm{l}}$ & $108.7 \mathrm{a}$ \\
$3 \times 11 / 2$ & 9,680 & $69.0 \mathrm{~b}$ & $78.8 \mathrm{~b}$ \\
$2 \times 2$ & 10,890 & $61.0 \mathrm{~b}$ & $83.6 \mathrm{~b}$ \\
$3 \times 2$ & 7,260 & $53.8 \mathrm{~b}$ & $58.0 \mathrm{c}$ \\
\hline
\end{tabular}

1 Treatments with different letters are significantly different at 5-percent level.

increase of 19.4 hundredweights of taniers per acre under reduced rainfall at Orocovis when the combined plant spacing of 3 by 2 feet with 7,260 plants per acre was decreased to 3 by 1 feet with 14,520 plants.

The narrow spacing of 2 by $11 / 2$ feet with a higher plant density per acre, significantly increased the number of marketable tubers above the 3 by 2 and 3 by 11/2 feet spacings at the 1-percent level of probability, and above the 2 by 2 feet spacing at the 5-percent level of probability (table 1). The intermediate spacings of 2 by 2 and 3 by 11/2 feet significantly produced more marketable tubers than the wider spacing of 3 by 2 feet at the 5-percent level of probability. No significant differences were observed between the intermediate plant spacings themselves.

None of the spacing treatments had a significant effect on tuber size as expressed by tuber mean weight (table 2).

Morada and Blanca del País cultivars significantly outyielded the Kelly cultivar by 26.3 and 22.7 hundredweights per acre, respectively, at the 1-percent level of probability (table 3). No significant differences were registered between Morada and Blanca del País. 
Blanca del País cultivar produced more marketable tubers than Kelly and Morada (table 3). However, the Morada cultivar produced heavier tubers as expressed by tuber mean weight (table 3). Both differences in number of marketable tubers and tuber mean weight were highly significant at the 1-percent level of probability.

The estimated production of the three cultivars herein reported is within the average yield range generally obtained by farmers and similar to that reported by Acosta-Matienzo and Vélez-Santiago (2) in three different localities of Puerto Rico. However, in an experiment established the previous year by the authors in the same site but under furrow irrigation,

TABLE 2.-Mean tanier tuber weight as affected by plant spacing and plant density

\begin{tabular}{ccc}
\hline Plant spacing & Plant density per acre & Tuber mean weight \\
\hline Peet & Number & Pounds \\
$3 \times 2$ & 7,260 & 0.223 \\
$3 \times 116$ & 9,680 & .212 \\
$2 \times 11 / 2$ & 14,520 & .207 \\
$2 \times 2$ & 10,890 & .199 \\
\hline
\end{tabular}

1 No significant differences at 5-percent level.

TABLE 3.-Estimated yield, number and mean weight of marketable tubers of three tanier cultivars

\begin{tabular}{cccc}
\hline Cultivar & Yield estimate per & Tubers per plot & Tuber mean weight \\
\hline & Aundredweights & Number & Pounds \\
Morada & $76.5 \mathrm{~b}^{\mathbf{1}}$ & $83.3 \mathrm{c}$ & $0.242 \mathrm{~b}$ \\
Blanca del País & $72.9 \mathrm{~b}$ & $97.3 \mathrm{~b}$ & $.195 \mathrm{a}$ \\
Kelly & $50.2 \mathrm{a}$ & $66.3 \mathrm{a}$ & $.193 \mathrm{a}$ \\
\hline
\end{tabular}

1 Treatments with different letters are significant at 1-percent level.

Blanca del País, Kelly, and Morada yielded 160, 129, and 116 hundredweights per acre, respectively. Apparently, the rather late planting date of August and the planting on unfurrowed flat soil may have had an adverse effect on the crop yield.

Considering that 5- to 6-man days are required to plant an acre of tanier with the wider 3 by 2 feet spacing, twice as many man-days probably would be required to carry out the same practice with the closer 2 by $11 / 2$ feet spacing. However, the initial higher cost of planting at a closer spacing is compensated later by a reduction in the number of hand weedings needed to maintain the compact field free of weeds. Although the experimental field was hand-weeded twice, the 2 - by $11 / 2$-feet plots were weeded only once. 


\section{SUMMARY}

Three tanier cultivars were planted at the Gurabo Substation in August 1971 to evaluate the effect of plant density on marketable yield, number of marketable tubers, and tuber mean weight of three tanier cultivars, namely, Blanca del País, Kelly and Morada.

The plant density treatments used per acre were: combinations of 3 between rows by 2 feet between plants with 7,260 plants; 3 by $11 / 2$ feet with 9,680 plants, 2 by 2 feet with 10,980 plants; and 2 by $11 / 2$ feet with 14,520 plants.

The results showed that plant spacing $X$ cultivar interaction was not significant. In other words, the cultivars responded similarly to the different planting treatments. The combined space planting of 2 by $11 / 2$ feet with 14,520 plants per acre significantly outyielded the other spacing treatments. A significantly higher number of marketable tubers was also recorded in this treatment. None of the planting treatments had a significant effect on tuber mean weight.

Aside from the plant spacing treatments, the cultivars Morada and Blanca del País significantly outyielded the Kelly cultivar. Blanca del Pais produced significantly more marketable tubers than the other cultivars, but Morada produced significantly heavier tubers.

\section{RESUMEN}

En agosto de 1971 se estableció un experimento en la Subestación de Gurabo, en el que se evaluó el efecto de la densidad de la población sobre el peso y número de tubérculos mercadeables y peso promedio de los tubérculos de tres variedades de yautía, a saber, Blanca del País, Kelly y Morada.

Los tres tratamientos utilizados, es decir, las combinaciones de distancias de siembra y sus respectivas poblaciones por acre, fueron las siguientes: 3 pies entre hileras por 2 pies entre plantas, 7,260 plantas; 3 por $11 / 2$ pies, 9,680 plantas; 2 por 2 pies, 10,980 plantas; y 2 por $11 / 2$ pies, 14,520 plantas.

Los resultados indican que la interación entre la distancia de siembra y el cultivar no fue significativa respecto a los criterios que se consideraron. En otras palabras, los cultivares respondieron en forma similar irrespectivamente de las distintas distancias de siembra. La combinación de 2 por $11 / 2$ pies de distancia con una población de 14,520 plantas por acre aumentó significativamente tanto el peso de los tuberculos mercadeables en comparación con las demás combinaciones, como el número de tales tubérculos. Ninguno de los tratamientos combinados tuvo efecto significativo en cuanto al peso promedio de los tubérculos.

Aparte de los efectos registrados para los tres tratamientos, las variedades Morada y Blanca del País tuvieron un rendimiento significativamente 
superior al de la Kelly. La yautía Blanca del País produjo un número significativamente mayor de tubérculos mercadeables que las otras dos, pero el peso promedio de los tubérculos fue significativamente mayor en la variedad Morada.

\section{LITERATURE CITED}

1. Abruña-Rodríguez F., Boneta-García, E. G., Vicente-Chandler, J., and Silva S., Experiments on tanier production with conservation in Puerto Rico's mountain region, J. Agr. Univ. P.R., 51 (2): 167-75, 1967.

2. Acosta-Matienzo, A., and Vélez-Santiago, J., Yield trials with Xanthosoma varieties, J. Agr. Univ. P.R., 54 (3) : 562-9, 1970.

3. Barrett, O. W., Las yautías de Puerto Rico, P.R. Agr. Exp. Sta. Bull. 6, 15 pp., 1805.

4. Enyi, B. A. C., Effect of spacing, set size, ridging and mulching on the development and yield of cocoyam, Xanthosoma sagittifolium (L.) Schott, Trop. Agr. 44 (1): 53-60, 1967.

5. Robert, R. C., Soil Survey of Puerto Rico, Bur. of Pl. Ind., Series 1936 (8) : 313-6, USDA, 1942. 